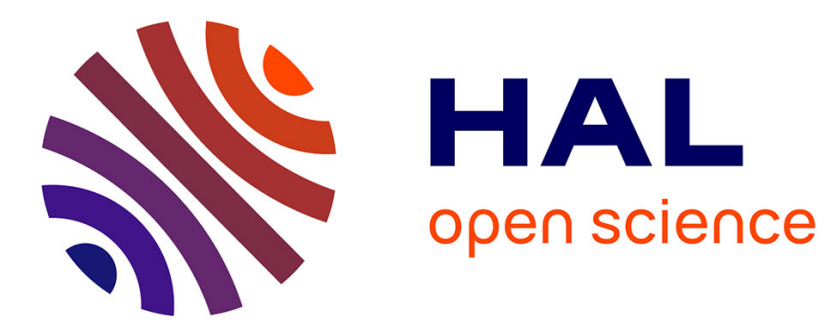

\title{
Unconventional oil and gas in France: From popular distrust to politicization of the underground
}

Sébastien Chailleux, Julien Merlin, Yann Gunzburger

\section{To cite this version:}

Sébastien Chailleux, Julien Merlin, Yann Gunzburger. Unconventional oil and gas in France: From popular distrust to politicization of the underground. The Extractive Industries and Society, 2018, 5 (4), pp.682-690. 10.1016/j.exis.2018.05.007 . hal-01985836

\section{HAL Id: hal-01985836 https://hal.science/hal-01985836}

Submitted on 23 Jan 2019

HAL is a multi-disciplinary open access archive for the deposit and dissemination of scientific research documents, whether they are published or not. The documents may come from teaching and research institutions in France or abroad, or from public or private research centers.
L'archive ouverte pluridisciplinaire HAL, est destinée au dépôt et à la diffusion de documents scientifiques de niveau recherche, publiés ou non, émanant des établissements d'enseignement et de recherche français ou étrangers, des laboratoires publics ou privés. 


\title{
Unconventional oil and gas in France: from popular distrust to politicization of the underground
}

\author{
Sébastien Chailleux ${ }^{\mathrm{a}}$, Julien Merlin' ${ }^{\mathrm{b}}$, Yann Gunzburger \\ a Centre Emile Durkheim (Bordeaux, France) and Laboratoire Passages (Pau, France), \\ s.chailleux@gmail.com \\ - Université de Lorraine, CNRS, LabEx Ressources21 (Nancy, France) and Centre de \\ Sociologie de Ið̊nnovation, Mines ParisTech (Paris, France), julien.merlin@outlook.com \\ - Université de Lorraine, CNRS, GeoRessources, Ecole des Mines de Nancy (Nancy, \\ France), yann.gunzburger@univ-lorraine.fr
}

\section{Abstract}

France has a long history in mining and, to a lesser extent, in hydrocarbon extraction, but these industries were both in decline by the end of the $20^{\text {th }}$ century. Following the American

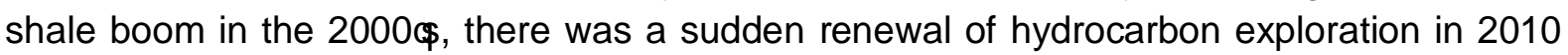
with new exploration licenses being delivered for unconventional oil and gas projects. These projects first remained confined to specialists of such industries until the end of 2010, when a massive social movement opposed shale gas exploration. This paper aims at drawing a picture of this social movement and its narrative work to obtain the ban on hydraulic fracturing by the French government in 2011. We show that i) public and political perceptions of unconventional gas in general were built mostly during the sudden burst of mobilization in late 2010 , with the opponent $\hat{\mathbf{S}}$ narratives encountering almost no resistance, ii) previous knowledge and experience with extractive industries in some areas of France facilitates social license there, but it does not guarantee the development of the industry, iii) the controversy about hydraulic fracturing participated to shape negative perception about extractive industries in France in general, including ore mining.

Keywords Unconventional resources; France; Social movement; Hydraulic fracturing; Ore mining

\section{Highlights}

ǒ A renewal of hydrocarbons and mining exploration took off in France in the 2010s.

ǒ Social perceptions of unconventional gas were built during a sudden mobilization.

ǒ Previous experience with extractive industries could facilitate social license locally.

ǒ The controversy about fracking shaped a negative perception about mining in general.

\section{Introduction}


France has a long history in mining and, to a lesser extent, in hydrocarbon extraction, but these industries were both in decline by the end of the $20^{\text {th }}$ century as a consequence of increasingly difficult geological conditions of exploitation (greater depth, lower gradesé ) associated in a context of international competition with other countries, and . However,

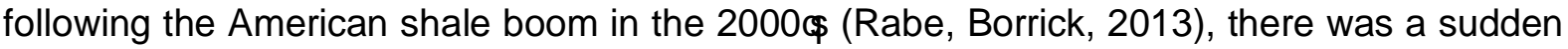
renewal of hydrocarbon exploration in 2010 with new exploration licenses being delivered for unconventional oil and gas projects in metropolitan France (Figure 1, left). These projects first remained confined to specialists of such industries until the end of 2010, when a massive social movement opposed shale gas exploration. Public pressure pushed the French government to ban hydraulic fracturing in 2011.

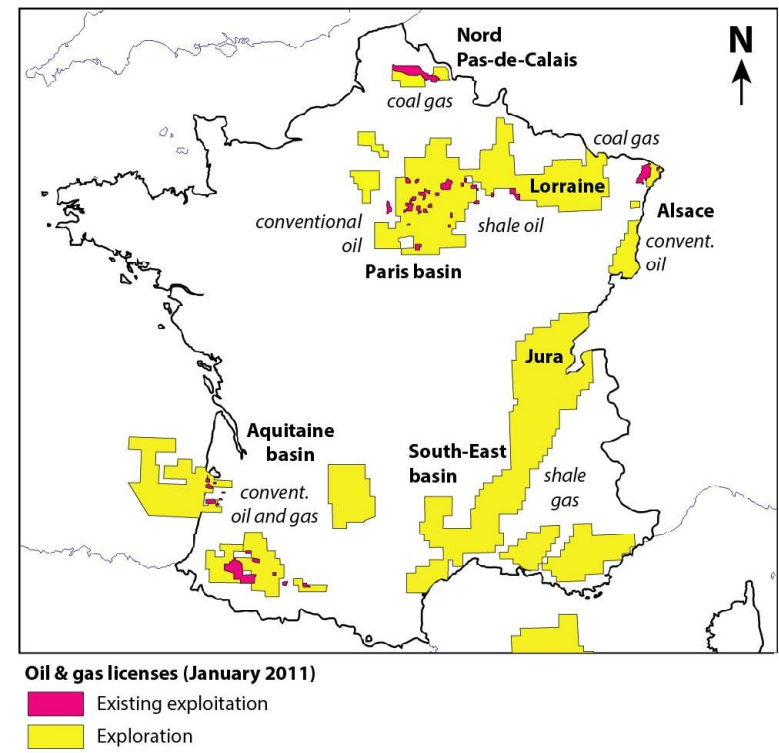

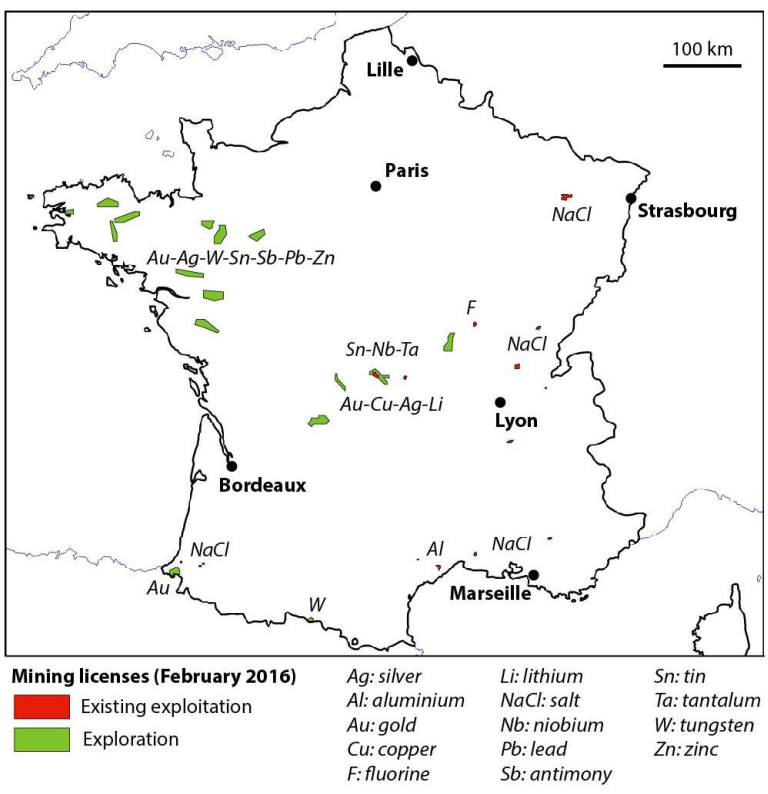

Figure 1

This article aims at analyzing conflicting politicization of unconventional oil and gas in France to show how the controversy over shale gas shaped new representations of the exploitation of sub-surface resources, regarding not only hydrocarbons, but also other mineable ore deposits. Our analysis does not seek to explain individual representations of unconventional hydrocarbons. Rather, it aims at understanding collective perceptions, and more exactly how those perceptions are shaped by political work. We thus build our study on a nuanced definition of social acceptability defined by Fortin and Fournis $(2013,2014)$ as: i) a microsocial process of meaning occurring within local communities, ii) a mesopolitical context of institutional compromises which encompass national regulation as well as previous energy choices or particular paths of economic development, and iii) a macroeconomic frame that allows or forbids profitability and defines a model of development. Following this definition, we are interested in explaining how unconventional hydrocarbons are defined by the various actors engaged in shaping energy policies. 
Our research is grounded in policy analysis and the sociology of controversies. These two fields of research help us grasp how public representations of unconventional oil and gas have framed public policy. We address public problems as social constructions (Gusfield, 1981), just as we do for policy setting (Rochefort, Cobb, 1993) and solutions (Kingdon, 1984). All three are shaped by the influence of policy actors who range from elected officials to scientific experts, associations, oil and gas companies, or citizens. Public policies are not considered to be the result of neutral and rational processes expressing the common good represented within Parliament; rather, they are the outcome of conflicts between various interests who are often described through the concepts of r̃coalitionò (Sabatier, JenkinsSmith, 1993; Hajer, 1993) or m̃networkò(Le Galès, Thatcher, 2000).

Our research targets the narratives used by political actors to assess how they contribute to the production of meaning for policy-making (Fischer, Forester, 1993; Zittoun, 2013). In analyzing how various coalitions of actors questioned the representation of the exploitation of underground resources, we are able to stress the politicization of previously unnoticed or unconsidered parts of the environment (Dø̂trcimoles, Borraz, 2003). Politicization means that actors produce and broadcast a new qualification for an object, which is here the underground. They do so by producing new resources such as knowledge, discourses, or alliances. Oren and Oren (2011) have demonstrated, for example, how discourses against gold mining trickled down $і$ or failed to trickle down ï into local communities in four locations in Turkey, highlighting the role of the first coalition who takes the lead in the persuasion process. [1]

Coalitions confront each other $\hat{\mathbf{S}}$ resources in various arenas that can be political (the Parliament, for example), public (public hearings or meetings), scientific (expertsô assessment, symposia), administrative or in the media. We thus followed the actors into those arenas to understand how they transform their argumentation to resist counterarguments (Chateauraynaud, 2011). The role of public debate (Blatrix et al., 2007) and the process of expertise (Jasanoff, 2004) are particularly important because they contribute to the definition of the stakes in play. Hereafter, we aim to underline how those two arenas allow some publics to participate in the framing of public policies. We highlight how policy work problematizing unconventional oil and gas is not so much fueled by negative perceptions as it is by technical questioning of the industry. We then expand the analysis to the whole oil and gas industry and to the mining industry in general.

This article is based on three sources of data. First, an analysis of the French press establishes different trends in the discourses mobilized between 2008 and 2013, and the actors supporting those claims. Second, 25 interviews were conducted between 2012 and 2014 with actors engaged in the shale gas controversy ${ }^{1}$ to understand their representations of oil and gas projects. Other interviews were conducted during a research program on a coalbed-methane project in the Lorraine region (northeastern France, Figure 1) between 2013 and 2015. Third, an analysis of the actors engaged in shaping public policy on shale gas was realized through the analysis of official reports. We analyzed which actors were

\footnotetext{
1 Those actors were selected based on press analysis and following snowball effect. They are representative of the public actors expressing their views in the media (scientists, officials, opponents, promoters) even if interviews with top ranked officials and industrials such as CEO and Ministers were not possible.
} 
heard by different committees and what kind of resources they mobilized to suggest policy solutions. The mapping of actors and discourses shows their relative importance in the controversy and their sway on policy solutions.

This research aims at describing this social movement and the narrative work undertaken to obtain the ban on hydraulic fracturing in 2011 (Terral, 2012; Chateauraynaud, Debaz, 2011; Chailleux, 2016; Zittoun, Chailleux, forthcoming). It also analyzes how opposition to fracking trickled down to the coalbed-methane project in Lorraine, even if the latter does not make use of this specific extraction technique (Gunzburger et al., 2017), and later to all hydrocarbons exploration, and even new mining projects (Merlin, forthcoming).

\section{Managing the decline of mining and oil-and-gas industries in France (1990-2005)}

The French mining industry played a key-role in the economic recovery after World War II. In the 1950s, coal mining was employing about 300,000 people in France and was producing around 60 million tons per year at its maximum, which represented $80 \%$ of the French coal consumption. In the same period, there were about 25,000 iron miners. The French uranium production record was reached in 1988 and represented half of the domestic consumption at that time. Nevertheless, in spite of increasing raw material consumption, a decline of the French mining activity started in the late 1980s; the last mines closed in 1997 for iron, 2003 for potash, and in the 2001-2004 period for uranium, coal, and gold.

Contrary to the France $\hat{\Phi}$ mining industry, its oil and gas industry has always been quite small, essentially for geological reasons. At the most, in the mid-1960s, the domestic crude oil production was only covering about $5 \%$ of the national consumption. French hydrocarbon production was halved between 1990 and 2000 because of the depletion of some of its exploitation fields, but mostly because of an international stock market making French energy and natural resources too expensive. Since the end of gas production from the Lacq field (Bassin dôAquitaine, Figure 1) in 2013, almost all the gas consumed in France has been imported, while only $1 \%$ of the French oil needs are covered by domestic production.

Before the American shale boom (2001-2009) and the concomitant world rush on mineral resources (2005-2010), economic and political interest in the underground was waning in France. During the $90 \mathrm{~s}$, the underground had progressively gone from being representative of wealth production, first and foremost in coal- and iron-mining areas (such as in the North, Northeast and South of France), to the being a symbol of the end of the French raw materials industry and to a source of geotechnical and environmental residual risks, which need to be monitored and managed. The decline also generated sclerosis in administrative processes that were not up-to-dated with new public participation practices.

On the mining side, the period following mine closure is commonly referred to as "postmining". This term indicates, on one hand, the end of mine exploitation, as well as the rise of new technical and political issues. The decline of mining activities in France imposed a big change in the action and the mission of the French State and its experts. During the 1990s and the 2000s, public organisms related to the mining sector were undergoing transformation. This is the case for the Center for Study and Research of Charbonnages de France (CERCHAR), which was created in 1947. This center was initially meant to promote technical progress at Charbonnages de France, a public institute established in 1946 to 
intensify coal extraction after the Second World War. The primary objective of the CERCHAR was to promote the knowledge and techniques needed to develop the French mining sector. In 1990, the CERCHAR became the INERIS, the French National Institute for Industrial Environment and Risks. Mine safety remains among its objectives, but the role of INERIS includes the evaluation and the prevention of risks incurred by the industrial sector, chemical substances, and underground exploitation on people $\hat{\Phi}$ safety and on the environment. With regard to mining, INERIS became a leader in the production of knowledge and instruments for old mining site monitoring in the 1990s. This new conception of the underground called for the application and the development of new kinds of expertise (for example, in geophysics and geotechnics) useful to the management of new issues, such as surface subsidence, water pollution, gas emissions, etc., all related to mine shutdown and their gradual flooding (for example, the first problems related to surface subsidence in the Lorraine region appeared in the 1996-1998 period). In 2001, the Groupement d'Intérêt Public (GIP) GEODERIS was created by the French geological survey (BRGM, Bureau de Recherches Géologiques et Minières) and the INERIS to offer assistance and expertise to the state (central administrations and local services) on "post-mining" issues. The French geological survey, which was created in 1959 to be in charge of research and management of mineral resources, changed its objectives and the scope of its engagements in 2006. Its new missions are to "manage, rehabilitate and monitor installations subject to the Environmental Code and located on mining sites" previously exploited by a public institution, a public company, or one of their subsidiaries. These are examples among many that illustrate how, the definition of the underground changed together with state responsibilities in France after 1990. The underground was no longer approached with the same kinds of expertise and knowledge, and environmental law and public safety became a central point in managing the impact of old mining activities.

On the oil and gas side, the residual French hydrocarbon extractive industry was mostly unknown outside a core set of specialists in the 2000s. Those experts were located in companies, a few research centers, and in the administrative department granting licenses. Two processes blinded these supporters of the industry and prevented them from noticing the coming controversy behind the exploration for unconventional hydrocarbons: first, the decline of the industry and the appearance of smaller companies with almost no political representation, and second, the marginalization of the administrative department granting the licenses. Those two processes impeded the visibility of the promoters of unconventional oil and gas exploitation.

By the end of the 1990s and at the beginning of the 2000s, oil majors such as Total and Shell sold their licenses to smaller companies because the remaining resources were deemed unprofitable. Companies such as Vermilion Energy and Lundin Petroleum became major players in France, but only with minimal extraction activity compared to the French consumption of oil. Nowadays, conventional oil is mainly produced in the Aquitaine and Paris basins (Figure 1). In Lacq (Aquitaine basin), Total demonstrated its ability to transform its gas exploitation, that ended in 2013 , into carbon capture and storage facilities with a pilot program built in 2009 to maintain industrial activity on site. Nevertheless, the areas concerned with oil and gas were, for the most part, less extensive and more spread out. Public and political concern shifted from oil and gas industry and the industry lost its attractiveness. As oil majors withdrew from exploration and exploitation activities, the professional association, Union Française des Industries Pétrolières (UFIP), became 
dominated by companies of oil refinement and distribution. So, when junior exploration companies arrived in the 2000s, they were outsiders in the profession, and did not have a reason to contribute to this professional association which did not support their claims and interests. In the 2000s, when hydrocarbons became an issue for experts again, they found no resonance with political and social claims (Zittoun, Chailleux, forthcoming).

The decline of the oil and gas industry also marginalized the administrative department in charge of licensing. The French Administration is composed of ministries divided into general directorates, subdivided into bureaus. Oil and gas licenses are granted by the Bureau Exploration Production Hydrocarbures (BEPH) under the supervision of the Direction Générale Energie-Climat (DGEC) in the Ministry of Ecology. Directors of DGEC changed, but the BEPH stayed the same. Because the topic of oil and gas did not interest politicallydriven actors in the DGEC, BEPH members had to explain their activity to every new director. In fact, the dominant French Corps des Mines (a group of engineers of high scientific level, generally dedicated to High Public Administration and assistance to political leaders), which play an influential role in many ministries and public companies, lost interest in mines and hydrocarbons. During this period, the BEPH also went from the Ministry of Industry to the Ministry of Ecology. This change brought new objectives that did not align with the usual frame of the civil servants at the BEPH, namely, production. The bureaus strictly applied the old Code minier (Mining law), relatively favorable to oil and gas companies. According to the French subsurface mineral rights, a mine has no private owner. Based on this, the state could give exploration licenses without consulting local governments and with no authorization from the landowners (exploitation licenses required public inquiry and consultation). Furthermore, the tax regime favors principally the central state depending on the amount of resources extracted, so, except for the landowners who could get compensation for the use of their land, local publics have no incentive to accept extractive industries. French institutions regulating mining and hydrocarbon exploration and exploitation are thus centralized, closed to external publics and unfavorable to municipalities.

\section{The prospects for unconventional resources as an economic opportunity (2005-} 2010)

In the early 2000s, the International Energy Agency (IEA) warned governments that oil and gas production would no longer match demand, calling at the same time for new exploration projects (IEA, 2004). Gas was then of the most favorable options for energy transition, with the IEA arguing for a r̃golden age of gasò(IEA, 2010).

Natural gas can be found in various forms and trapped in various rocks: reservoir (conventional), shale, tight, or coalbed methane (unconventional). France is deemed to possess the second most diverse shale resources in Europe after Poland (EIA, 2011). In March 2010, the French Minister of Environment issued three exploration licenses in southeastern France (Figure 1), involving the exploration of shale gas with hydraulic fracturing. Those licenses did not draw any significant attention at that time from elected officials or environmental associations. It is worthwhile to note that shale oil licenses were also issued in 2008 in the Paris basin and several tests involving hydraulic fracturing occurred (Bellec et al., 2012), but they were only contested later. We aim at explaining why the issuance of licenses did not generate controversy by analyzing how the very vocabulary used by specialists limited their ability to forecast potential problems. Not only were 
supporters of the industry scattered and marginalized, they also used vague notions such as ñunconventionalò and rexplorationò that contributed to blinding them to the nascent controversy.

The qualities of ñuconventionalòare left opened, and professional vocabulary blurs the line between unconventional gas, bedrock hydrocarbons, shale gas on the one hand, and hydraulic fracturing utilized for conventional exploitation on the other hand. In fact, if ñnconventionalò includes the controversial exploitation of the Canadian tar sands, its meaning is not quite stabilized (Zittoun, Chailleux, forthcoming). All the interviews conducted with professionals have shown how the very definition of what ñunconventionalò means fluctuates through time. Professionals debate whether the resource or the technique is unconventional. Some of them qualify the technique as unconventional because it is the degree of mastery of a technique that qualifies it as conventional. In the 1990s, conventional wells were exploited with vertical drilling into a reservoir. At this time, offshore deep drillings were considered unconventional because of their specificities, but they became mainstream in the 2000s. In the 2000s, horizontal drillings combined with hydraulic fracturing started to be used for unconventional resources such as shale gas and oil. However, in the same time, the same professionals explain that those techniques are not unconventional; the targeted resources are. They say that hydraulic fracturing is also used to stimulate conventional oil exploitation and that horizontal drillings could be used without hydraulic fracturing. Both techniques are deemed to be mastered by the oil companies for decades. Therefore, neither the Administration nor the companies foresaw the potential conflicts in hydraulic fracturing, a long-mastered technique. Hydraulic fracturing was seen as a technical solution for the exploitation of new sources of oil and gas that were not profitable before. Press analysis shows that most of the few articles published before December 2010 were quite positive toward hydraulic fracturing. This technology was seen through the prism of American shale boom, which brought increased tax revenues, profits, and energy independence.

Administrative processes distinguished between exploration and exploitation and participated in lessening attention to the problem. Exploration is seen as very uncertain as only one in ten explorations is a success. So, neither companies nor the BEPH foresaw the need to communicate with a wider public about the ongoing activity. Licenses were publicized in the Journal officiel and town halls, but unconventional oil and gas was not yet cast in a problematic light. Furthermore, licenses are only land-related; companies need to demand an authorization for drilling in other departments. The assessment of hydraulic fracturing is only done during this second process. Before December 2010, there was no actual drilling activity for shale gas, as the Schuepbach company only planned a first drilling in late 2011. Shale oil exploration is more advanced as Vermilion planned drilling operation in January 2011. Therefore, when shale gas licenses started to be contested, only the technical feasibility had been assessed, not the impact, as the process for authorization had only been anticipated.

Thus, the initial period of granting licenses was characterized by blindness to potential conflicts concerning hydraulic fracturing. The licenses targeting unconventional oil and gas were granted following the same process as conventional hydrocarbons and no actor took notice of the specificities of shale gas in the first few months. When the topic of unconventional oil and gas was addressed in the media, it was mostly in a positive fashion. 


\section{The flash-mobilization over the controversy on shale gas (2011)}

Unconventional oil and gas became a social and political topic in France in a fortnight because it relied on flash-mobilization (Terral, 2012; Chateauraynaud, Debaz, 2011). It succeeded in ascribing a new public meaning to hydraulic fracturing as a threat to the environment and public health and in enrolling most the French officials behind that definition (Author 1, forthcoming). This new public problem led to a ban on hydraulic fracturing within only six months, a very short time in French political processes.

In what follows, the process of imposing a negative frame on hydraulic fracturing will be analyzed in four steps. First, we show how collective action emerged and generated a discourse against hydraulic fracturing. Second, we underline how the criticism of shale gas turned into a political claim. Third, the lack of resistance from supporters is mobilized to explain the severity of the ban. Fourth, we show that the ban on hydraulic fracturing is a response to social unrest and, at the same time, a compromise that lets the door open.

A flash-mobilization was organized in the Ardèche department (Southeastern France) in December 2010. José Bové, an activist grounded in local networks against GMOs, organized a public meeting because one of the licenses targeted the Larzac plateau, a historic landmark for the French altermondialiste movement and for resistance to state infrastructures in the 1970s. This meeting gathered together activist networks and linked the negative impacts of hydraulic fracturing in the USA to the French licenses (Author 1, forthcoming). Therefore, from this meeting, a negative meaning was attached to hydraulic fracturing. At the same time, a sense of urgency spread, as opponents generated a discourse of imminent threat to the lands opened up to the shale gas industry.

From this public meeting, an extraordinary snowball effect is observable: public meetings grew exponentially in most of the hundreds of towns in the area concerned by licenses. In Ardèche alone, activists estimated the number of persons who attended these meetings at 45,000. The movie Gasland (Fox, 2010) was shown during most of the public meetings, and constituted a powerful and negative picture of what shale gas was supposed to be in the US. It is worthwhile to note that the new definition of hydraulic fracturing occurred outside of any official forum, even if opponents mobilized all sorts of expertise to backup their claims. Hydraulic fracturing was not defined as an innovation. Rather, it represented a new threat for the land, bringing industrial activities into rural areas. Critics of the technique relied on alternative assessments of its impact. For example, opponents reference the work of one local academic hydrogeologist from Montpellier who claimed that the specificities of the Southeastern French underground, made of faults and cavities, could not support the drilling of gas wells in a secure fashion (Université de Montpellier 2, 2011). Critics of hydraulic fracturing urged many mayors to take action against shale gas by issuing public statements or municipal bylaws to oppose heavy truck driving, denying water provision or symbolically banning hydraulic fracturing.

Initially, the anti-shale gas discourse was critical of the administrative process, which did not compel companies and the state to communicate with local officials and populations ${ }^{2}$ and it

\footnotetext{
${ }^{2}$ Actually, this was not exactly the case because the information was public, but it did not mean anything before the mobilization.
} 
targeted hydraulic fracturing as the main threat for locals because i) it generates risks to groundwater, ii) it competes with other uses of surface water, and iii) it deteriorates landscapes (see Figure 2). All of those local actions contributed to wide press coverage, mostly at the regional level, because every action led to an article repeating anti-shale gas arguments and stressing the need for the cancellation of the contested licenses. The rantio discourse was not only about these localized projects, but rejected all kinds of hydrocarbon projects as the motto of opponents was: r̃shale gas, not here, not anywhereò Therefore, critics of shale gas encompassed many issues that would interest allies: water for farmers, landscapes and land-planning for mayors, pollution for local communities. The collective action successfully associated a future threat with the local land, generating a need for immediate action.

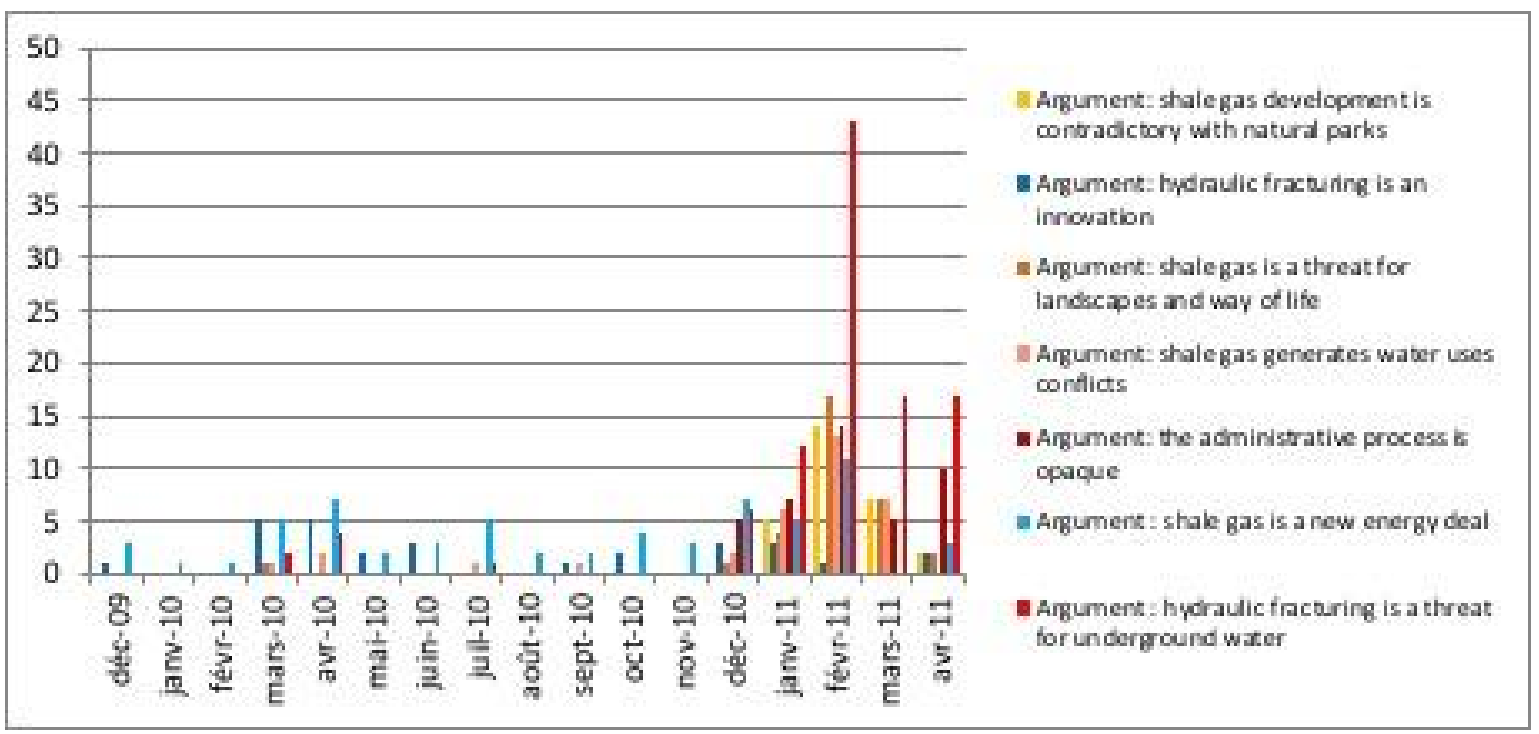

Figure 2

The flash-mobilization initiated in the South-East percolated to the Paris basin (center of France, Figure 1) in February 2011. The common claim was about the cancellation of the licenses but it was the use of hydraulic fracturing which concentrated all the rejection. The Paris basin didn $\hat{\phi}$ raise the same concerns about landscapes because it is mainly an area of productive agriculture which was already used for small-scale conventional oil exploitation. Here, hydraulic fracturing was defined as a threat for underground water because the areas concerned provide the 10 million inhabitants of the Paris area with fresh water. Moreover, the area covered by the licenses was located in the districts of majority leaders of parliament, a year before the general election of 2012 .

No political support for shale gas was audible during this period. Even though some timid supporters reminded journalists of the American experience (trade balance, royalties, jobs, energy independence. For example: see Nodé-Langlois, ñn eldorado pétrolier sous le Bassin parisienò Le Figaro, March 2011; Grasland, ñes gaz non conventionnels pourraient augmenter de 60 \% les ressources européennesò Les Echos, March 2011), it did not compete with the anti-shale gas discourse (Figure 2). Companies were disorganized and in disagreement on the value of unconventional oil and gas. Lundin, for example, didn $\hat{\Phi}$ want anything to do with those projects. Companies such as Vermilion Energy who had both conventional exploitation and unconventional exploration projects soon withdrew their 
unconventional projects from the table to preserve their conventional wells from protests. Total had only obtained a license in France to master hydraulic fracturing associated with horizontal drillings, so the potential economic impact was not so significant for the company. Only two junior companies had strong interests in those unconventional projects: Schuepbach Energy for shale gas and Toreador for shale oil. They were both eager to validate potential resources in order to sell back their licenses to major companies (as Toreador did with Hess Oil). European Gas Limited (EGL), which was conducting a coalbedmethane project in Lorraine (Northeastern France, Figure 1), also participated to hearings in order to dissociate its activities from hydraulic fracturing. The company stressed the specificities of the Lorraine coal that is deemed to allow the extraction of coalbed methane without using hydraulic fracturing, due to the fractures it naturally bears. During this period, industry supporters only tried to prevent the controversy from expanding to conventional oil and gas activities.

The first responsible parties targeted by opponents were the oil and gas companies, but then the State was made responsible and enjoined to take action to stop the unrest. Opponents claimed for the cancellation of the contested licenses. Therefore, political action needed to be taken by the government. The Minister of Ecology took the lead on the problem. She was newly nominated and dissociated herself from the former minister who signed the licenses. Early February 2011, she asked for an administrative committee to review the grant of those licenses and for companies to wait before starting any new drillings. This did not have any impact on mobilization, which was peaking with a massive protest in Villeneuve-de-Berg by the end of February. By this time, it became obvious for officials that only a ban could stop the unrest. By the end of March, the majority leader introduced a bill to ban hydraulic fracturing. To set the unrest, the parliament forbade the use of hydraulic fracturing because it was the only legal option to cancel the licenses without being held responsible for legal pursuits from companies. The Jacob Act forbids hydraulic fracturing but allows experimentation and foresees an annual revision of the ban based on technological progress. Following the ban, the three licenses targeting shale gas were cancelled but the licenses for shale oil stayed valid as they also targeted conventional oil. The companies could pursue their activities but without hydraulic fracturing. In July 2011, the dominant public representation was that hydraulic fracturing is an uncertain and threatening technique, but the status of the unconventional resources remained unresolved.

This period was characterized by a blitzkrieg on the meaning of hydraulic fracturing. The technology transitioned from being covert to overt, but more importantly the owners of the dominant discourse shifted. From December 2010 onward, the owners of the definition of hydraulic fracturing were opponents who stressed the threat to groundwater and public health posed by the use of chemicals, the competition for the use of surface water, the destruction of landscapes and ways of life the drillings would produce and the lack of supervision from the state. This negative perception of hydraulic fracturing was translated into law in July 2011 with a ban on hydraulic fracturing.

\section{The spillovers toward the oil-and-gas industry (2012-2017)}

The ban on hydraulic fracturing did not entirely close the controversy, and then began a guerrilla war. The representation of the oil and gas industry did not improve after 2011.On the contrary, mistrust percolated down to many drilling projects, leading to an organized 
phasing out of hydrocarbon production. Representation of the industry moved from bad to worse according to three dynamics that we will explain. First, the technical cognitive frame over hydraulic fracturing engaged promoters on the path for alternative techniques and failed attempts to reverse the law. Second, the search for alternative techniques and the door left open to experimentation kept the social mobilization on hydrocarbons alive. Protests continued at a smaller scale and the movement set in. Third, the supporters lost most of their political allies and, in 2017, this lack of interest led to a final political decision on the end of all hydrocarbon production in France by 2040.

It is worthwhile to note that even if the general meaning of the Jacob Act resonates with the claims of opponents, the bill also translated the claims of proponents who were mainly represented during the various hearings organized by official reporters. Even if the ban was necessary, supporters advocated limiting its impact on conventional exploitation. This points out that the cognitive frame of the French policy on hydrocarbon remains dominated by industrial and scientific actors. Table 1 shows what types of actors were heard during the committee hearings.[2] We observe that the controversy did not integrate forums for public debate as most of the people heard were experts and proponents of the industry.

\begin{tabular}{|c|c|c|c|c|}
\hline & \multicolumn{4}{|c|}{ Official reports } \\
\hline Type of public & $\begin{array}{l}\text { Gonnot- } \\
\text { Martin } 2011\end{array}$ & $\begin{array}{c}\text { CGIET/CGEDD } \\
2012\end{array}$ & $\begin{array}{c}\text { Havard- } \\
\text { Chanteguet } \\
2011\end{array}$ & $\begin{array}{l}\text { OPECST } \\
2013\end{array}$ \\
\hline Central administration & $13.5 \%$ & $6.1 \%$ & $12 \%$ & $10.7 \%$ \\
\hline Foreign administration & $15.1 \%$ & $16.2 \%$ & $0 \%$ & $5.4 \%$ \\
\hline Local administration & $4.7 \%$ & $10.6 \%$ & $0 \%$ & $11.8 \%$ \\
\hline $\begin{array}{l}\text { Representative/Political } \\
\text { party }\end{array}$ & $4.8 \%$ & $2.2 \%$ & $4 \%$ & $0 \%$ \\
\hline $\begin{array}{l}\text { Company/Professional } \\
\text { association }\end{array}$ & $42 \%$ & $34.1 \%$ & $72 \%$ & $49.5 \%$ \\
\hline Research center/Scientist & $4.8 \%$ & $15 \%$ & $12 \%$ & $19.3 \%$ \\
\hline Individual & $4 \%$ & $0 \%$ & $0 \%$ & $0 \%$ \\
\hline ENGO/Local committee & $10.3 \%$ & $12.3 \%$ & $0 \%$ & $3.2 \%$ \\
\hline Other & $0.8 \%$ & $3.3 \%$ & $0 \%$ & $0 \%$ \\
\hline Total in number/percentage & $126 / 100 \%$ & $179 / 100 \%$ & $25 / 100 \%$ & $93 / 100 \%$ \\
\hline
\end{tabular}

Table 1 - Categories of members of the public heard by authors of the reports 
Since the Jacob Act allows experimentation and foresees annual revision of the ban, there was an opening for companies. Even though most of the companies withdrew their interests from unconventional projects, some still believed it was possible to change the law in a foreseeable future. On this topic, the new socialist government elected in 2012 was divided between the opponents to all kinds of exploration of unconventional resources gathered behind the Ministry of Ecology, and the proponents of alternative techniques and r̃ leanò hydraulic fracturing gathered behind the Minister of Industry, Arnaud Montebourg. The ñechnological frameòin the Jacob Act permits such spillovers to occur around the question of alternative techniques. Indeed, by limiting questioning about shale gas to only the specific technology used to access and produce the resource, industrials and supporters aimed at excluding opponents from debates. In fact, many specialists interviewed did not value the expertise borne by opponents despite its influence on policy-making. Their counterdiscourse brought forward the need for exploration in order to evaluate resources and the necessary experimentation over hydraulic fracturing. The major supporters of the alternative techniques discourse were not oil companies but a handful of elected officials from the Parliamentary office of technological assessment (Office Parlementaire dïEvaluation des Choix Scientifiques et Techniques : OPECST in Table 1) and research centres on oil, such as the Institut Français du Pétrole et des Energies Nouvelles. Those actors pushed for the implementation of experimentation from 2012 onwards. The OPECST published a report in November 2013 praising the use of hydraulic fracturing. Minister Montebourg did the same the following year when he mandated a report on fluoropropane fracturing. All these attempts failed to change the law. During the same time, EGL successfully drilled a well and proved its capacity to extract coalbed methane without hydraulic fracturing in 2014 . The company allied with the Regional Council and the Ministry of Industry in order to participate in an investment plan of 300 million euros on a three-year period to create a ñalley of energy and materialsòin order to reindustrialize the Lorraine region.

In July 2013, after months of uncertainty, President Hollande declared there wouldn $\boldsymbol{\Phi}$ be any shale gas exploration during his mandate. Attempts to change the law failed because social mobilization was still active after the ban. The core-set of activists regarded the Jacob Act as a scam to demobilize opponents; they continued to mobilize against all unconventional projects even though the mobilization in south-eastern France decreased. In 2012, they targeted coalbed methane in Lorraine, but failed to find resonance with local issues. Local opponents were broadcasting the same discourse as they had for shale gas. They failed to oppose the exploration on the ground of the threats of hydraulic fracturing, because in that case there was no use of that technique. Elsewhere, opponents obtained a few victories when they opposed exploratory licenses targeting shale layers without the mention of hydraulic fracturing. In fact, the blurry lines between conventional and unconventional resources benefited opponents who prevented the granting of some licenses on the grounds of suspicion of hydraulic fracturing, as in the case of Moussières license in Jura (Eastern France). Relying on previous negative experience with Shell in the 1990s, locals aimed at preserving fresh water wells and argued against the license. Opponents made use of various kinds of expertise to oppose those licenses as they faced different contexts: tight-gas in the Gardanne license (SE France), coalbed methane in Lorraine, an offshore license in Mediterranean Sea. Between 2012 and 2017, only a handful of exploration licenses were granted because the Ministry did not want to generate social unrest. Out of about a hundred demands per year, the few that were granted went mostly to conventional oil and coalbed 
methane. The struggle to attract political attention was finally won by opponents as the attempts to modify or to fully implement the ban all failed. The discourse of opponents developed to encompass all kind of hydrocarbon and to promote the energy turn.

After the dismissal of Montebourg in late 2014, the hydrocarbon industry lost its first-line ally and it became more undisclosed. Coalbed methane projects in Lorraine lost the support of the Ministry of Industry and started to be criticized not for the use of hydraulic fracturing but

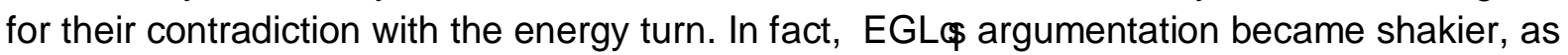
the positive impacts for Lorraine became somehow uncertain with taxes being possibly lower than expected, jobs creation minimal, and there may be no subsidized local price for gas. Furthermore, social acceptance of the projects couldn $\hat{\Phi}$ be assured, as coalbed-methane production would occur at the outskirts of previous mining extraction zones, in areas with no previous experience with mining (Gunzburger et al., 2017).

The place of gas in the energy turn was also criticized because some unconventional gases produce more GHG than conventional ones, so their carbon footprint is not that advantageous. Even though the industry organized into a lobby dedicated to unconventional oil and gas in 2015, it did not manage to obtain political attention in the months preceding the COP21 (United Nations Climate Change Conference) in Paris. The political agenda was then focused on the energy turn and ways of reducing GHG emissions. France could not afford to grant new licenses for oil and gas and advocate reducing oil consumption at the same time. Following the COP21 and the election of Macron as President in 2017, oil and gas exploitation was in a difficult position. There was no public and political support for those activities except very locally in the Total stronghold in Lacq. The nomination of Nicolas Hulot, a former environmental activist and TV host, as Minister of Ecological Transition, closed the door to any improvement for the industry. In the fall of 2017, Hulot passed a bill to forbid the granting of new licenses and to put an end to hydrocarbon extraction by 2040 .

\section{How the negative meanings of hydrocarbons projects percolated to mining exploration (2012-2017)}

In the 2000s the French state also renewed its interest in mining exploitations with the project proposed by Arnaud Montebourg in early 2014, who was planning on creating a "French company of mines". Using past studies from BRGM, the aim of the project was to guarantee France's supply of certain mineral resources by creating a national mining company responsible for exploiting the French underground resources and offering a longterm guarantee. Based on the last mining inventory carried out by BRGM in 1992, the public institution began a campaign for the revaluation of the available data in 2012. In this framework, a map of French "mining potential" was created through the identification of several sites and resources that could be exploited. From 2013 on, several new mine exploration licenses have been delivered by the government (Figure 1, right) for the first time since 30 years.

The project of creating a national mining company was finally abandoned after the resignation of Montebourg in 2014. Nevertheless, this did not permanently bury the project of a potential revival of mining activities in France, which was supported by Emmanuel Macron, the Minister of the Economy at that time. In February 2015, the French Government adopted a national strategy for the ecological transition towards sustainable development 2015-2020 
(SNTEDD) during the Council of Ministers. Under the support of Emmanuel Macron, a thinktank was established with the aim of defining the concept of "responsible mine" and its practical implementations. This group was constituted by mining industries and their experts, public institutes, as well as collectives involved in environmental protection and people coming from the academic world. The objective was to define a new partnership between the state and the stakeholders, which were first of all mining companies, to think of a new mining model focused on the reduction and the prevention of environmental and social impacts. Engaging with all the stakeholders from the start, the "responsible mine" method integrated the establishment and the settlement of the involved society in its objectives. This helps anticipate social, territorial, and environmental management of the "post mining" era and to prepare land recovery. The social acceptability of mines was an issue directly considered by French State in the "responsible mine" project. The territorial mining history together with its social and environmental impacts helped to frame new debates on a potential mineral revival.

At the local level, the French mining renewal and several mining exploration projects are contested especially between 2015 and 2018. These disputes are brought by local populations, local environmental protection associations, but also by several national and international NGOs. Our study has shown that these different types of collectives are connected. To understand the extent of their claims and representations, it is necessary to study their relationships and how they build what we propose to name a r̃ommon causes". For example, in French Brittany, various local associations contest mining exploration projects by denouncing their hypothetical impacts on the environment. Criticizing the impacts of mining drilling on the Breton underground, they contest the consultation processes of the local populations, and promote ecological development projects (like ecotourism). For them, the French mining renewal must also be discussed at the regional and municipal level. But theses local associations also work with nationals and international NGOs like Friends of the Earth. Their joint work has contributed to the emergence of a global critique of extractivism in France. Their common cause proposes to connect technical issues (environmental impacts) with economic, political, and legal claims (against the mining renewal, for the reform of the French mining code for example). It is interesting to note that Friends of the Earth had established the same type of relationship with local associations regarding the shale gas controversy.

The comparison between the two controversies allows us to propose several things. First, we note that very strong links exist between the rejection of shale gas operations in France, and the rejection of the mining renewal. Secondly, we suggest that this rejection is not the result of an "NIMBY" syndrome, but on the contrary the renewal of collective problematization, both local and global, of the French underground. Local, national and international collectives are asking that the future of the French underground be discussed in consideration of several problems they are connecting: impacts of mining activities, representation of local populations, economic relevance of the mining renewal in France, especially in comparison with other projects of development. These problems are both presented as local, national and international issues.

\section{Discussion}

Analyzing the French unconventional oil and gas case, we want to assert four arguments. 
First, public and political perceptions of unconventional oil and gas developed mostly during the sudden burst of mobilization in late 2010. At that time, opponent $\hat{\Phi}$ narratives encountered almost no resistance, so negative perception quickly percolated to the media and officials. Our data suggests that before the controversy over shale gas in early 2011, unconventional oil and gas was an obscure topic that only interested specialists. Unconventional hydrocarbons were framed as an energy New Deal and hydraulic fracturing as technical innovation, but they did not echo with political aspirations. Most importantly, at the local level, elected officials were not interested in those projects in an efficient way due to centralized and confined licensing. When the topic burst to public attention, it was through the heady discourse of anti-fracturing opponents. Public and political perceptions were then formatted mostly through negative arguments. Despite few governmental attempts to defuse the critics, the absence of a rapid reaction among promoters combined with the efficient broadcasting of critical discourse in the media and public forums, thanks to an abundance of collective action, led to a ban on hydraulic fracturing within only six months.

Second, previous knowledge and experience with extractive industries in some areas of France (such as former coal and iron mining basins) facilitated social licensing there, but it did not guarantee the development of the industry. The political framing of hydraulic fracturing allowed another unconventional gas industry to develop, namely, coalbed methane. In this case, local characteristics played a crucial role in supporting the potential industry. Among these were the need for industrial reconversion, previous experience with mining, and political support. Coalbed methane projects succeeded in being part of a regional plan for re-industrialization and local opposition was for a moment downsized. However, following the controversy over shale gas, all hydrocarbons came to be targeted as an issue. Elsewhere, previous experience with mining and hydrocarbons did not offer such support to unconventional oil and gas. Near Paris, previous conventional oil exploitation did not support shale oil exploration due to the use of hydraulic fracturing, and most of the companies engaged in the exploration backed off for fear of the repercussions on their conventional wells. In Jura (Eastern France), previous experience even played a negative role, serving as an impetus to a critical stance toward new projects. Therefore, previous knowledge and experience does not mean an absence of criticism. In fact, it can be a strain to new projects when the previous ones have had negative social or environmental impacts at the time of their closure.

Third, the controversy about hydraulic fracturing participated in shaping negative perception about all extractive industries in France. The 2011 ban did not put an end to social mobilization; rather it lead to a period of further social distrust in conventional oil exploration licenses. In 2017, a bill was introduced in Parliament to ban all hydrocarbon exploitation by the end of 2040. Therefore, hydraulic fracturing contributed to politicizing the underground as an object of environmental preoccupation (Elden, 2013; Bebbington, Bury, 2016; Svampa, 2016).

Fourth, the French case shows that the representations of the underground are constructed through a technical and social questioning of the effects of the industry. The questions contribute to generating a politicization of the issues of activities related to the underground that unfold at different scales of public and collective action. Thus, the politicization of the underground is based on a symbolic and narrative construction that integrates the materiality 
of local resources and targeted techniques. Hydraulic fracturing offers large catches to criticism that are used to build a legal prohibition, first partial then general. Conversely, the specificities of the Lorraine coal, for example, are used to exclude the use of hydraulic fracturing and favour the deployment of the industry. The territory where the extraction projects are set up is therefore a space of confrontation between global dynamics (market logic, scientific evaluation of the carbon footprint of the gas, etc.), national dynamics (social movement, revision of the mining code, Jacob law, partisan political game) and local dynamics (representation of the territory, local planning policies, partisan political issues).

\section{Conclusion}

The process of social perception of hydrocarbons in France relies on multiple streams that we analysed at three analytical level (micro, meso, macro). The renewal of interest in the French underground was led by a macro-dynamic based on the prices of natural resources and geopolitical relations. The liberal and capitalist frame for the exploitation of hydrocarbons favours private investments, but it also generates constraints for the acceptability of the projects. The example of local pricing for Lorraine coalbed methane is a blatant contradiction between this macroeconomic frame and the local interests allowing the development of the industry.

The perceptions are then shaped at the mesopolitical level that is based mostly on the subsurface regulation, which in our case is centralized, closed to non-specialists and local actors and disconnected from local land planning. The institutions governing the underground appeared out-dated and a reform of the Code minier (mining law) has been planned since 2011, as the regulation is not up-to-date with regard to environmental law. Mesopolitical agreements therefore favored a critical stance towards the underground as they did not foresee the need for upstream public participation.

Social perceptions were determined at the micro level where actors interacted with each other. Controversies over the underground show how local actors generated their own expertise on complex topics because they were critical of the knowledge propagated by private companies and the administration. They manufactured new meanings for the industry and its technologies that were successfully broadcasted in the media and public forums through social mobilization.

The French case demonstrates this complex process leading to the politicization of the underground. Oil and gas projects, and mining projects, were subjected to criticism because of the political work of local and national actors who produced a negative meaning for those industries. This social perception was not only locally rooted, but also relied on a global critique of hydrocarbon as the path of development. Negative meanings of oil and gas are thus not an expression of the ñNot in my backyardò (NIMBY) syndrome, but a local translation of a general movement rejecting technological fixes for environmental issues.

\section{Acknowledgments}


Part of this work has been supported by the Région Lorraine and by the French National Research Agency (ANR) through the national program ñnvestissements d'avenirò with the reference ANR-10-LABX-21-01/LABEX RESSOURCES21.

\section{$\underline{\text { References }}$}

Blatrix, C. et al. 2007. Le Débat public: une expérience française de démocratie participative. La Découverte.

Chailleux, S. 2016. Incertitude et action publique. Définition des risques, production des savoirs et cadrage des controverses. Revue internationale de politique comparée. 23/4, 519548

Chateauraynaud, F. 2011. Argumenter dans un champ de force. Paris: Petra.

Chateauraynaud, F., Debaz, J. 2011. Lôffaire des gaz de schiste. Anatomie dône mobilisation fulgurante [Online: http://socioargu.hypotheses.org/3262].

Conseil général de lôndustrie, de lễnergie et des technologies, Conseil général de ḷ̂̂nvironnement et du développement durable, 2012. Les hydrocarbures de roche-mère en France. République française.

DâArcimoles, M., Borraz, O. 2003. Réguler ou qualifier. Le cas des boues dẽeuration urbaine. Sociologie du travail. 45, 45-62

Elden, S. 2013. Secure the volume: vertical geopolitics and the depth of power. Political geography. 34, 35-51

Energy information administration, 2011. World shale gas resources. US EIA

Fischer, F., Forester, J. 1993. The argumentative turn in policy analysis and planning. Duke University Press

Fortin, M.-J., Fournis, Y. 2015. Une participation conflictuelle : la trajectoire territoriale des mobilisations contre le gaz de schiste au Québec, Participations. 13, 119-144.

Fortin, M.-J., Fournis, Y. 2014. Vers une définition ascendante de lâcceptabilité sociale IIlles dynamiques territoriales face aux projets énergétiques au Québec. Natures Sciences Sociétés. 22/3, 231-239.

Fortin, M.-J., Fournis, Y. 2013. Facteurs pour une analyse intégrée de lếcceptabilité sociale selon une perspective de développement territorial: Iôndustrie du gaz de schiste au Québec. Université du Québec à Rimouski.

Gunzburger, Y., Agnoletti, M.-F., Deshaies, M., Ferey, S., Raggi, P. 2017. Social acceptability of an economic revival project based on subsurface resources exploitation: example of coalbed methane in Lorraine, France. The Extractive Industries and Society, 4 (1), 53-62 (doi: 10.1016/j.exis.2016.12.006)

Gusfield J. 1981. La culture des problèmes publics. Lốlcool au volant : la production dên ordre symbolique. Paris: Economica. 
Hajer, M. 1993. Discourse coalition and institutionalization of practice: the case of acid rain in Britain ", in John Forester, Frank Fischer. The argumentative turn in policy analysis and planning. Duke Univeristy Press: London.

International Energy Agency, 2011. Golden age of gas, Organisation de coopération et de développement économique.

Le Galès, P., Thatcher, M. 2000. Les réseaux de politique publique: Débat autour des policy networks. Paris: Lơlarmattan.

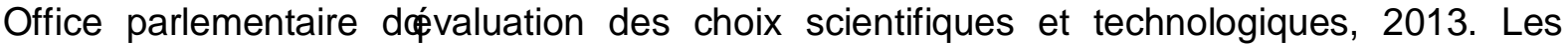

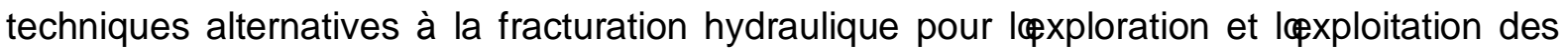
hydrocarbures non conventionnels. Paris: Assemblée nationale et Sénat.

Özen, H., Özen, S. 2011. Interactions in and Between Strategic Action Fields: A Comparative Analysis of Two Environmental Conflicts in Gold-Mining Fields in Turkey. Organization Environment, 24 (3).

Rabe, B., Borrick, C. 2013. Conventional Politics for Unconventional Drilling? Lessons from

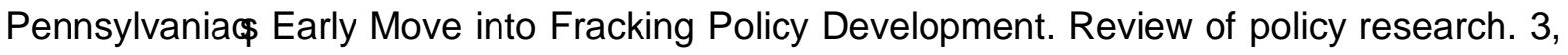
321-340

Rochefort, D., Cobb, R. 1993. The politics of Problem Definition: Shaping the Policy Agenda. University Press of Kansas

Svampa, M. 2016. Reconfiguration du clivage Nord-Sud et géographie de l'extraction. Alternatives Sud, 23.

Terral, P.-M. 2012. La fronde contre le gaz de schiste $\mathbb{\text { ll }}$ essai dø̂istoire immédiate dône mobilisation éclair (2010-2011). Ecologie \& politique. 45/2, 185-202.

Université de Montpellier 2, 2011. Gaz de schiste, les questions qui se posent. Université de Montpellier

Zittoun, P. 2013. La fabrique politique des politiques publiques. Paris: Presses de Sciences Po

[1] Following those approaches over bundles of actors gathering around common grounds, we aim at showing that there is no general public with perception over an issue. We rather understand as the public of a particular controversy the actors mobilized on various levels to assert a position on the topic (Dewey, 1929).

[2] Gonnot-Martin report came from the parliamentary committee launched in March 2011 and published in June 2011. CGIET-CGEDD report came from the administrative committee mandated in February 2011. Havard-Chanteguet report is the parliamentary report on the Jacob bill. OPECST report is a made by the parliamentary office for technological assessment on alternative techniques in 2013. 


\section{Figure captions}

Figure 1. Map of hydrocarbon and mining licenses in France in 2011 and 2016 respectively. Names of geological regions and cities are given in bold. Types of hydrocarbons and ores are given in italic.

Figure 2. Main arguments described in 334 press articles (2009-2011). 